Volume 10, Issue 6, November-December 2019, pp. 275-286, Article ID: IJM_10_06_027

Available online at http://iaeme.com/Home/issue/IJM?Volume $=10 \&$ Issue $=6$

Journal Impact Factor (2019): 9.6780 (Calculated by GISI) www.jifactor.com

ISSN Print: 0976-6502 and ISSN Online: 0976-6510

C IAEME Publication

\title{
AN OVERVIEW AND SIGNIFICANCE OF DIFFERENT BANCASSURANCE SCHEMES LAUNCHED FOR FINANCIAL INCLUSION IN INDIA
}

\author{
Puja Dua \\ Research Scholar, Amity University Noida, India \\ Dr Namita Sahay \\ Associate Professor, Amity University Noida, India
}

Dr O S Deol

Associate Professor, Bhagat Singh College (E), Delhi University, India

\begin{abstract}
Bancassurance is a relationship between a bank and an insurance company that aims to provide customers of the bank with insurance products or insurance benefits. The objective of the research paper is to provide an overview of Bancassurance products \& schemes launched by the government and the private banks to contribute towards the financial inclusion of the nation. The authors furthermore discussed and provides the details of various schemes launched by government such as Life Cover under Pradhan Mantri Jan Dhan Yojana (PMJDY), Pradhan Mantri Jeevan Jyoti Bima Yojana (PMJJBY), Pradhan Mantri Vaya Vandana Yojana (PMVVY), Pradhan Mantri Fasal Bima Yojana (PMFBY), and other such schemes. The methodology adopted for the research is to review the published articles and the reports and to summarise the significance and the importance of the bancassurance towards the financial inclusion of the country. The finding of the study concluded that the bancassurance schemes launched by the government of India and the schemes run by the private banks to increase the bancassurance percentage in the country are having significant positive results. There are still the number of issues needs to be addressed to achieve the $100 \%$ financial inclusion in the country.
\end{abstract}

Keywords: Bancassurance; Financial inclusion; India; Banks; PMJDY; PMJJBY.

Cite this Article: Puja Dua, Dr Namita Sahay, Dr O S Deol, An Overview and Significance of Different Bancassurance Schemes Launched for Financial Inclusion in India, International Journal of Management (IJM), 10 (6), 2019, pp. 275-286.

$\mathrm{http}: / /$ iaeme.com/Home/issue/IJM?Volume $=10 \&$ Issue $=6$ 


\section{INTRODUCTION}

\subsection{Bancassurance}

Bancassurance is a relationship between a bank and an insurance company that aims to provide customers of the bank with insurance products or insurance benefits. Bank staff and tellers become the customer's point of sale and point of contact in this partnership. With wholesale product information, marketing campaigns and sales training, bank staff are advised and supported by the insurance company. The commission is shared by the bank and the insurance company. Insurance policies are processed by the insurance company and administered [1].

Both companies can profit from this partnership arrangement. Banks can earn additional revenue through the sale of insurance products, while insurance companies can expand their customer base without expanding their sales forces or paying insurance agents or brokers commissions. Bancassurance has proved to be an effective distribution channel in Europe, Latin America, Asia, and Australia in several countries [2], [3].

Bank insurance is still generally banned in some nations but has recently been permitted in countries such as when the Glass-Steagall Act was abrogated. But in recent years revenues have been modest and flat, with most insurance sales of US banks being mortgage insurance, life insurance, or loans-related property insurance. But in recent times China has allowed banks to buy insurers and vice-versa, boosting the banking insurance product and some major global insurers in China have witnessed a huge expansion in banking sales to individuals across various product lines [4]-[6].

\subsection{Private Bank Insurance Providers}

Private bank insurance is a wealth management process developed and used globally by Lombard International Assurance. The theory blends private banking and investment management services with innovative use of life-safety as a framework for financial planning to gain fiscal advantages and protection for rich investors and their families. The banks are the representative for insurance companies, which gradually sell their policies. Bancassurance is high productivity and low-cost efficient distribution channel than conventional distribution channels [7]-[9].

In the modern banking unit, the workers are named by an insurance company to support banking customers with their insurance solutions. Integrated models' is a profoundly integrated insurance activity into bank processes. Premium is usually collected by the bank, usually direct debit from the customer's bank account. In branches of the bank, new business data are entered and workflows are automated between the bank and insurance companies. In most cases, asset management is carried out by the subsidiary of the bank's asset management [10]-[12]. Bank branches receive life insurance sales commissions. Some commissions may be paid to employees of the branch as commissions or bonuses based on the achievement of sales goals.

The sale of branch insurance products by branch personnel has been restricted by regulatory restrictions because most investments can only be sold with permitted financial advisors who have obtained a minimum qualification.' Non-integrated models. As a result, banks have set up networks of financial advisors authorized to sell insurance products regulated. They usually operate as tied agents and only sell products made by the in-house insurance company or third-party providers of the bank [13]-[15]. 


\subsection{Role of the Agents}

Insurance products are distributed by branch staff, sometimes supported with more sophisticated products or certain customer types by specialist insurance counselors. Life insurance products are fully integrated into the bank's range of savings and investment products, with industry employees selling an increasing number of insurance products, e.g. protection, health or non-life products, which are moving farther away from their core activities [16], [17]. Products are primarily medium-and long-term investment products that benefit from the tax. They are specifically designed to meet the needs of branch consultants in terms of simplicity and similarity with banking products. These products often have a lowrisk component of insurance in particular [18]-[20].

\section{LITERATURE REVIEW}

Table 1 Summary of previous studies in Bancassurance

\begin{tabular}{|c|c|}
\hline References & Findings \\
\hline $\begin{array}{l}{[2],[21]-} \\
{[24]}\end{array}$ & $\begin{array}{l}\text { The high cost of circulation fundamentally constraining the vast majority of the protection } \\
\text { players to disregard the provincial market and offer just that much which is required } \\
\text { according to IRDA direction as stipulated in their business operations. Along these lines, it } \\
\text { turns into a commitment for insurance agencies to enter in the rustic market, as opposed to } \\
\text { looking at this specific market as another business opportunity. }\end{array}$ \\
\hline $\begin{array}{l}{[2],[25]-} \\
{[27]}\end{array}$ & $\begin{array}{l}\text { Under any conditions, there ought not to be an alternative for strategically pitching of any sort } \\
\text { of budgetary items which does not satisfy the money related prerequisite of the individual } \\
\text { customers. }\end{array}$ \\
\hline $\begin{array}{l}{[10],[13]} \\
{[14],[28],} \\
{[29]}\end{array}$ & $\begin{array}{l}\text { From the request (or firm) side of the credit advertise, hypothetical work on the development } \\
\text { of obligation structure had proposed an association between data issues and firms' obligation } \\
\text { development decisions }\end{array}$ \\
\hline [30]-[33] & $\begin{array}{l}\text { Counting the improvement of PC frameworks enabling banks to exploit strategically pitching } \\
\text { openings, faculty preparing and promoting costs with advantages, for example, deals edges } \\
\text { and other backhanded advantages (e.g. expanding client steadfastness). }\end{array}$ \\
\hline $\begin{array}{l}{[34]-} \\
{[36][37]-} \\
{[41]}\end{array}$ & $\begin{array}{l}\text { Expanded firms had values that were } 13 \% \text { to } 15 \% \text { beneath the aggregate of the attributed } \\
\text { estimations of their portions, however, this misfortune was moderated in instances of more } \\
\text { engaged expansion inside related ventures. }\end{array}$ \\
\hline$[42]-[45]$ & $\begin{array}{l}\text { The driving force for the development of bancassurance as an appealing channel for } \\
\text { circulation of protection items can be given by banks and insurance agencies by concentrating } \\
\text { on all parts of administration quality specifically responsiveness, affirmation, substantial- } \\
\text { quality, sympathy and unwavering quality }\end{array}$ \\
\hline$[46]-[48]$ & $\begin{array}{l}\text { Bancassurers, for the most part, forces an upper hand over their opposition since they could } \\
\text { complete intra-amass exchange (on occasion without right hazard assessments), and } \\
\text { additionally to upgrade prerequisites of dissolvability edge as per each kind of budgetary } \\
\text { operation inside the gathering. }\end{array}$ \\
\hline $\begin{array}{l}{[32],[46]-} \\
{[50]}\end{array}$ & $\begin{array}{l}\text { Enhancement may prompt an enhanced rating for the association. Different advantages would } \\
\text { incorporate enhanced resource administration and more successful utilization of value capital. } \\
\text { The befuddle between bank resources (long haul) and liabilities (here and now) may be the } \\
\text { invert from that of a safety net provider (long haul commitments). }\end{array}$ \\
\hline $\begin{array}{l}{[2],[3],} \\
{[25],[27]}\end{array}$ & $\begin{array}{l}\text { Managing an account protection mixes had a tendency to lessen hazard however keeping } \\
\text { money securities or land blends were hazarded expanding. }\end{array}$ \\
\hline$[4]-[6],[19]$ & $\begin{array}{l}\text { Credit advertise chain of importance exists among private obligation (inside bank advances), } \\
\text { private arrangement (inside insurance agency securities) and general society obligation } \\
\text { showcase (outside obligation). }\end{array}$ \\
\hline$[7]-[9],[51]$ & $\begin{array}{l}\text { Safety net providers, as a rule, lost an incentive thus of these occasions; banks neither lost nor } \\
\text { picked up esteem. }\end{array}$ \\
\hline $\begin{array}{l}{[7],[11],} \\
{[51],[52]}\end{array}$ & $\begin{array}{l}\text { Specialists proposed that for India, The Bancassurance Model ought to be embedded well } \\
\text { ordered beginning from straightforward items and afterwards ought to be stretched out to }\end{array}$ \\
\hline
\end{tabular}




\begin{tabular}{|l|l|}
\hline & complex items. \\
\hline $\begin{array}{l}\text { [6], [8], } \\
{[10]-[12],} \\
{[14]}\end{array}$ & the administration needs to put more prominent endeavours into enhancing execution \\
\hline$[13],[15]$, & $\begin{array}{l}\text { In the 1990s, banks gained significant ground in customary protection exercises, with } \\
\text { different annuity speculation contracts and consolidated investment funds and protection } \\
\text { contracts (known as entire life coverage) in the United Kingdom. }\end{array}$ \\
\hline$[53],[54]$ & $\begin{array}{l}\text { In the UK, a review demonstrated that bancassurance had a generous cost advantage over } \\
\text { normal UK life workplaces of comparable profiles in 1998. TSB Life appreciated a 30.2\% } \\
\text { cost favorable position and Black Horse Life 22.2\% }\end{array}$ \\
\hline$[18],[22]$, & $\begin{array}{l}\text { The central explanations behind low use of the capability of bancassurance are - monopolistic } \\
\text { relations, a low point of preparing, nonappearance of operational coordination, unequal } \\
\text { relationship, brief-term of tie-ups, absence of uncommonly considered items, non-use of } \\
\text { mechanical stage and deprived adjusting guidelines charming in the bancassurance way }\end{array}$ \\
\hline $\begin{array}{l}\text { The sort of relationship procedure which might be actualized in the event of the office-based } \\
\text { framework, the same may not appropriate for bancassurance channel where both the specialist } \\
\text { organizations and administration beneficiaries may differ impressively. Therefore the creator } \\
\text { proposes that a different preparing instrument should be produced for the improvement of the } \\
\text { whole business. }\end{array}$ \\
\hline$[34],[48]$, & $\begin{array}{l}\text { The insurance agencies understood the need to build up an option channel through which they } \\
\text { can reach to the mass fragment at any rate cost. This brings bancassurance as a favored } \\
\text { method of dispersion of protection items where the division is yet to reach. This may ready to } \\
\text { manage the money related consideration as proposed by the administrations. }\end{array}$ \\
{$[57]$}
\end{tabular}

\begin{tabular}{|c|c|c|c|c|}
\hline S.No & Scheme name & beneficiary & $\begin{array}{c}\text { launch } \\
\text { date }\end{array}$ & Features \\
\hline 1 & $\begin{array}{l}\text { The National Agricultural } \\
\text { Insurance Scheme } \\
\text { (replacing the erstwhile } \\
\text { Comprehensive Crop } \\
\text { Insurance Scheme (CCIS) }\end{array}$ & farmers & 1999 & $\begin{array}{l}\text { The new scheme is now available to all the } \\
\text { farmers-loanee and non-loanee-irrespective } \\
\text { of their size of holding. It envisages coverage } \\
\text { of all the food crops (cereals, millets and } \\
\text { pulses), oilseeds and annual } \\
\text { horticultural/commercial crops, in respect of } \\
\text { which past yield data is available for adequate } \\
\text { number of years }\end{array}$ \\
\hline 2 & RuPay Card & All & $\begin{array}{l}26 \\
\text { March } \\
2012 .\end{array}$ & $\begin{array}{l}\text { RuPay is offering complimentary personal } \\
\text { accident insurance and permanent total } \\
\text { disability cover on all RuPay Debit Card } \\
\text { variants (i.e.) RuPay Classic, RuPay Platinum } \\
\& \text { PMJDY etc. The available sum insured on } \\
\text { RuPay Debit Cards will be Rs. } 2.00 \text { Lac on } \\
\text { RuPay } \\
\text { Platinum Debit Card and Rs. } 1.00 \text { Lac on } \\
\text { RuPay Classic Debit Card respectively. }\end{array}$ \\
\hline 3 & $\begin{array}{l}\text { Urban Financial Inclusion } \\
\text { Programme (UFIP) }\end{array}$ & $\begin{array}{l}\text { urban poor, slum } \\
\text { dwellers and } \\
\text { inhabitants of } \\
\text { urban/metro } \\
\text { villages }\end{array}$ & $\begin{array}{l}20- \\
\text { Dec-12 }\end{array}$ & $\begin{array}{l}\text { providing insurance and investment services } \\
\text { to the people by imparting financial literacy. }\end{array}$ \\
\hline
\end{tabular}




\begin{tabular}{|c|c|c|c|c|}
\hline 4 & Kisan Credit Cards & farmers & 1998 & $\begin{array}{l}\text { his model scheme was prepared by the } \\
\text { National Bank for Agriculture and Rural } \\
\text { Development on the recommendations of } \\
\text { R.V.GUPTA committee to provide term loans } \\
\text { for agricultural needs. Insurance coverage for } \\
\text { Kisan Credit Card holders, including asset } \\
\text { insurance and personal accident insurance } \\
\text { scheme (PAIS) }\end{array}$ \\
\hline 5 & $\begin{array}{l}\text { Varishtha pension bima } \\
\text { yojna }\end{array}$ & senior citizens & $\begin{array}{l}15 \text { th } \\
\text { August, } \\
2014\end{array}$ & $\begin{array}{l}\text { It will provide an assured pension based on a } \\
\text { guaranteed rate of return of } 8 \% \text { per annum for } \\
\text { ten years, with an option to opt for pension on } \\
\text { a monthly / quarterly / half yearly and annual } \\
\text { basis. The scheme provides pension in the } \\
\text { form of immediate annuity during the lifetime } \\
\text { of the pensioner with return of purchase price } \\
\text { to the family/nominee on his/her death }\end{array}$ \\
\hline 6 & $\begin{array}{l}\text { Pradhanmantri fasal bima } \\
\text { yojna }\end{array}$ & farmers & $\begin{array}{l}\text { 18th } \\
\text { Februar } \\
\text { y } 2016\end{array}$ & $\begin{array}{l}\text { The new Crop Insurance Scheme is in line } \\
\text { with One Nation - One Scheme theme. It } \\
\text { incorporates the best features of all previous } \\
\text { schemes and at the same time, all previous } \\
\text { shortcomings / weaknesses have been } \\
\text { removed. The PMFBY will replace the } \\
\text { existing two schemes National Agricultural } \\
\text { Insurance Scheme as well as the Modified } \\
\text { NAIS. There will be a uniform premium of } \\
\text { only } 2 \% \text { to be paid by farmers for all Kharif } \\
\text { crops and } 1.5 \% \text { for all Rabi crops. In case of } \\
\text { annual commercial and horticultural crops, the } \\
\text { premium to be paid by farmers will be only } \\
5 \% \text {. The premium rates to be paid by farmers } \\
\text { are very low and balance premium will be } \\
\text { paid by the Government to provide full } \\
\text { insured amount to the farmers against crop } \\
\text { loss on account of natural calamities. }\end{array}$ \\
\hline 7 & $\begin{array}{l}\text { restructured weather based } \\
\text { crop insurance scheme }\end{array}$ & farmers & $\begin{array}{l}\text { 18th } \\
\text { Februar } \\
\text { y } 2016\end{array}$ & $\begin{array}{l}\text { Restructured Weather Based Crop Insurance } \\
\text { Scheme (RWBCIS) aims to mitigate the } \\
\text { hardship of the insured farmers against the } \\
\text { likelihood of financial loss on account of } \\
\text { anticipated crop loss resulting from adverse } \\
\text { weather conditions relating to rainfall, } \\
\text { temperature, wind, humidity etc. RWBCIS } \\
\text { uses weather parameters as "proxy" for crop } \\
\text { yields in compensating the cultivators for } \\
\text { deemed crop losses. Payout structures are } \\
\text { developed to the extent of losses deemed to } \\
\text { have been suffered using the weather triggers. }\end{array}$ \\
\hline 8 & Atal pension scheme & $\begin{array}{l}\text { unorganized sector } \\
\text { workers }\end{array}$ & $\begin{array}{l}\text { 09 May } \\
2015\end{array}$ & $\begin{array}{l}\text { the government announced that it would co- } \\
\text { contribute } 50 \% \text { of the total contribution } \\
\text { or ₹ } 1,000 \text { (US\$14) per annum, whichever is } \\
\text { lower, to each eligible subscriber account, for } \\
\text { a period of } 5 \text { years. }\end{array}$ \\
\hline 9 & $\begin{array}{l}\text { Rajiv gandhi jeevandayee } \\
\text { arogya yojna(The scheme } \\
\text { is renamed as Mahatma } \\
\text { Jyotiba Phule Jan Arogya } \\
\text { Yojana (MJPJAY) from } \\
\text { 1st April 2017) }\end{array}$ & $\begin{array}{l}\text { health scheme for } \\
\text { ews in } \\
\text { Maharashtra- } \\
\text { holders of either of } \\
4 \text { cards of } \\
\text { Maharashtra govt- } \\
\text { antyodya card, } \\
\text { annapurna card, } \\
\text { yellow ration card, }\end{array}$ & $\begin{array}{l}\text { 2nd } \\
\text { July } \\
2012\end{array}$ & $\begin{array}{l}\text { The scheme entails around } 971 \\
\text { surgeries/therapies/procedures along with } 121 \\
\text { follow up packages in following } 30 \text { identified } \\
\text { specialized categories. up to Rs. } 1,50,000 /- \\
\text { per family per year }\end{array}$ \\
\hline
\end{tabular}




\begin{tabular}{|c|c|c|c|c|}
\hline & & orange ration card & & \\
\hline 10 & $\begin{array}{l}\text { Rashtriya swathya bima } \\
\text { yojna }\end{array}$ & $\begin{array}{l}\text { medicalim for } \\
\text { family of } 5 \text { living } \\
\text { bpl }\end{array}$ & $\begin{array}{l}01- \\
\text { Apr-08 }\end{array}$ & $\begin{array}{l}\text { It provides for cashless insurance for } \\
\text { hospitalisation in public as well as private } \\
\text { hospitals. }\end{array}$ \\
\hline 11 & $\begin{array}{l}\text { Ayushmanbharat health } \\
\text { scheme }\end{array}$ & poor families, & $\begin{array}{l}23-\text { Sep- } \\
18\end{array}$ & $\begin{array}{l}\text { The scheme offers an insurance cover of Rs } 5 \\
\text { lakh, which will cover almost } 50 \text { crore } \\
\text { citizens. there will be no cap on the family } \\
\text { size and age under the AB-NHPS. The scheme } \\
\text { will be cashless and paperless at public } \\
\text { hospitals and empanelled private hospitals. }\end{array}$ \\
\hline \multirow[t]{9}{*}{12} & $\begin{array}{l}\text { national social assistance } \\
\text { scheme (after failure of } \\
\text { Rajiv gandhi .....) }\end{array}$ & $\begin{array}{l}\text { provides financial } \\
\text { assistance to the } \\
\text { elderly, widows and } \\
\text { persons with } \\
\text { disabilities in the } \\
\text { form of social } \\
\text { pensions. }\end{array}$ & 1995 & $\begin{array}{l}\text { 1995: The NSAP is launched with the aim of } \\
\text { providing social assistance to destitutes } \\
\text { "defined as any person who has little or no } \\
\text { regular means of subsistence from his/her own } \\
\text { source of income or through financial support } \\
\text { from family members or other sources". The } \\
\text { NSAP includes three components: National } \\
\text { Old Age Pension Scheme (NOAPS), National } \\
\text { Family Benefit Scheme (NFBS), and National } \\
\text { Maternity Benefit Scheme (NMBS). }\end{array}$ \\
\hline & & & & $\begin{array}{l}\text { 2000: Annapurna Yojana is introduced to } \\
\text { provide eligible beneficiaries, who were not } \\
\text { covered under NOAPS, } 10 \mathrm{~kg} \text { of free rice.[2] }\end{array}$ \\
\hline & & & & $\begin{array}{l}\text { 2001: NMBS is transferred to the Department } \\
\text { of Family Welfare. }\end{array}$ \\
\hline & & & & $\begin{array}{l}\text { 2006: Monthly pension amount for NOAPS } \\
\text { raised from ₹75 (US\$1.10) } \\
\text { to ₹200 (US\$2.80) [2] }\end{array}$ \\
\hline & & & & $\begin{array}{l}\text { 2007: The NSAP is extended to cover all } \\
\text { individuals living below the poverty line. The } \\
\text { NOAPS is renamed Indira Gandhi National } \\
\text { Old Age Pension Scheme (IGNOAPS). }{ }^{[2]}\end{array}$ \\
\hline & & & & $\begin{array}{l}\text { 2009: The NSAP is expanded to include the } \\
\text { Indira Gandhi National Widow Pension } \\
\text { Scheme (IGNWPS) }{ }^{[3]}-\text { for widows aged } 40- \\
64 \text { years - and the Indira Gandhi National } \\
\text { Disability Pension Scheme (IGNDPS) }{ }^{[4]}-\text { for } \\
\text { persons with multiple or severe disabilities } \\
\text { aged } 18-64 \text { years living below the poverty } \\
\text { line. }\end{array}$ \\
\hline & & & & $\begin{array}{l}\text { 2011: Age limit for IGNOAPS is lowered } \\
\text { from } 65 \text { to } 60 \text { years under IGNOAPS and } \\
\text { monthly pension amount for those } 80 \text { years } \\
\text { and above is raised from ₹ } 200 \text { (US\$ } 2.80 \text { ) } \\
\text { to ₹500 (US\$7.00).[5] Age limits for } \\
\text { IGNWPS and IGNDPS are changed to 40-59 } \\
\text { and } 18-59 \text {, respectively. }\end{array}$ \\
\hline & & & & $\begin{array}{l}\text { 2012: Monthly pensions under IGNWPS and } \\
\text { IGNDPS increased from ₹200 (US\$2.80) } \\
\text { to ₹300 (US\$4.20). Age limit changed to } 40- \\
79 \text { years and } 18-79 \text { years, respectively. }\end{array}$ \\
\hline & & & & $\begin{array}{l}\text { 2013: Report of the Task Force on } \\
\text { Comprehensive Social Assistance Programme } \\
\text { submitted to the Government of India. } \\
\text { Recommends raising monthly pension and } \\
\text { expanding coverage. }\end{array}$ \\
\hline 13 & $\begin{array}{l}\text { Pradhan Mantri Vaya } \\
\text { Vandana } \\
\text { Yojana(PMVVY) }\end{array}$ & Old age peoples & $\begin{array}{l}\text { 4th } \\
\text { May, } \\
2017\end{array}$ & $\begin{array}{l}\text { insurance against future interest income } \\
\text { decreasing due to uncertainty on the market } \\
\text { and to social security at an old age, the }\end{array}$ \\
\hline
\end{tabular}




\begin{tabular}{|c|c|c|c|c|}
\hline & & & & $\begin{array}{l}\text { decision has been made to implement a } \\
\text { simplified system of guaranteed pensions } \\
\text { Towards' is introduced by India's Life } \\
\text { Insurance Corporation (LIC)//Process and } \\
\text { analysing of RBI and Govt reports issued on } \\
\text { PMVVY }\end{array}$ \\
\hline 14 & $\begin{array}{l}\text { Pradhan Mantri Fasal } \\
\text { Bima Yojana (PMFBY) }\end{array}$ & Farmers & $\begin{array}{l}13-01- \\
2016\end{array}$ & $\begin{array}{l}\text { PMFBY offers comprehensive insurance } \\
\text { protection against the cultivation loss, which } \\
\text { helps to sustain farmers ' incomes and allows } \\
\text { them to pursue creative practices/PMFBY } \\
\text { offers comprehensive insurance protection } \\
\text { against the cultivation loss, which helps to } \\
\text { sustain farmers ' incomes and allows them to } \\
\text { pursue creative practices//Process and } \\
\text { analysing of RBI and Govt reports issued on } \\
\text { PMFBY }\end{array}$ \\
\hline 15 & $\begin{array}{l}\text { Pradhan Mantri Suraksha } \\
\text { Bima Yojana(PMSBY) }\end{array}$ & $\begin{array}{l}\text { people between } 18 \\
\text { and } 70 \text { years old }\end{array}$ & $\begin{array}{l}08-05- \\
2015^{\prime}\end{array}$ & $\begin{array}{l}\text { The policy is offered by Public Sector General } \\
\text { Insurance Companies or any other Insurance } \\
\text { Company which is willing to offer the product } \\
\text { with requisite approvals on similar terms and } \\
\text { tie it up with banks to do so. } \\
\text { The Scheme is available to people between } 18 \\
\text { and } 70 \text { years old with a bank account who } \\
\text { offer their permission to enter/activate an } \\
\text { annual renewal of self-debit before or on } 31 \\
\text { May for the coverage period from } 1 \text { June to } 31 \\
\text { May./Process and analysing of RBI and Govt } \\
\text { reports issued on PMSBY }\end{array}$ \\
\hline 16 & $\begin{array}{l}\text { Pradhan Mantri Jeevan } \\
\text { Jyoti Bima Yojana } \\
\text { (PMJJBY) }\end{array}$ & $\begin{array}{l}\text { For poor and the } \\
\text { people not having } \\
\text { financial services }\end{array}$ & $\begin{array}{l}09-05- \\
2015^{\prime}\end{array}$ & $\begin{array}{l}\text { The premium is Rs. } 330 \text { per year and shall be } \\
\text { automatically debited to one instalment for the } \\
\text { bank account of the subscriber according to } \\
\text { the options provided by him on or before } 31 \\
\text { May of each annual coverage period under the } \\
\text { scheme/Process and analysing of RBI and } \\
\text { Govt reports isued on PMJBY }\end{array}$ \\
\hline 17 & $\begin{array}{l}\text { Life Cover under Pradhan } \\
\text { Mantri Jan Dhan Yojana } \\
\text { (PMJDY) }\end{array}$ & BPL & $\begin{array}{l}28- \\
\text { Aug-14 }\end{array}$ & $\begin{array}{l}\text { Process and analysing of RBI and Govt } \\
\text { reports issued on PMJDY }\end{array}$ \\
\hline 18 & Micro Pension Model & $\begin{array}{l}\text { persons operating in } \\
\text { informal sector }\end{array}$ & & $\begin{array}{l}\text { Micro Pension Plan shall refer to an } \\
\text { arrangement for the provision of pension to } \\
\text { the self-employed and persons operating in the } \\
\text { informal sector through the } \\
\text { Contributory Pension Scheme. The primary } \\
\text { objective of Micro Pension Plan is to provide } \\
\text { retirement benefits to the Micro } \\
\text { Pension Contributor. }\end{array}$ \\
\hline 19 & Financial Inclusion Fund & & 2016 & $\begin{array}{l}\text { FIF and FITF were established in the year } \\
2007 \text { - } 2008 \text { over a period of five years } \\
\text { Initial corpus was } 500 \text { crore } \\
\text { Contribution of GOI, RBI and NABARD was } \\
\text { in the ration } 40: 40: 20 \\
\text { RBI framed guidelines for both these funds } \\
\text { RBI merged both funds into a single entity } \\
\text { named FIF and came into effect in } 2016\end{array}$ \\
\hline
\end{tabular}




\section{SCHEMES LAUNCHED BY GOVERNMENT OF INDIA FOR BANCASSURANCE}

\subsection{Life Cover under Pradhan Mantri Jan Dhan Yojana (PMJDY)}

In his Independence Day Speech, the Hon'ble Prime Minister unveiled an ambitious financial inclusion program targeted at a large number of those who are currently without even basic financial services. In this direction, Pradhan Mantri Jan DhanYojana (PMJDY) is planned to provide every family which until now had no account with a basic bank account. The bank account requires a RuPay.

\subsection{Pradhan Mantri Jeevan Jyoti Bima Yojana (PMJJBY)}

The PMJJBY is open to people between 18 and 50 years of age who have a bank account, who agree to join / auto-debit. Aadhar would be the bank's main KYC. The life span of Rs. 2 lakhs will be renewable for a period of one year from 1 June to 31 May. In case of death of the insured, risk coverage under this scheme is, for any reason, for Rs. 2 Lakh. The premium is Rs. 330 per year and shall be automatically debited to one instalment for the bank account of the subscriber according to the options provided by him on or before 31 May of each annual coverage period under the scheme. The scheme is provided by Life Insurance Corporation and all other life insurers that are prepared to offer the product on the same terms with necessary approvals for this purpose and are linked to banks.

\subsection{Pradhan Mantri Suraksha Bima Yojana(PMSBY)}

The Scheme is available to people between 18 and 70 years old with a bank account who offer their permission to enter/activate an annual renewal of self-debit before or on 31 May for the coverage period from 1 June to 31 May. Aadhar would be the bank's primary KYC. The danger compensation for accidental death and full disability under the program isRs. 2 lakh, and for partial invalidity Rs.1 lakh. The fee of Rs. 12 annually must be deducted from the bank account of the account holder through a one-payment' auto-debit' facility. The policy is offered by Public Sector General Insurance Companies or any other Insurance Company which is willing to offer the product with requisite approvals on similar terms and tie it up with banks to do so.

\subsection{Pradhan Mantri Fasal Bima Yojana (PMFBY)}

On 14 January 2016, Pradhan Mantri Fasal Bima Yojna was launched to minimize agricultural distress and the welfare of farmers without impacting the sharp rise in the minimum price support of agricultural products (MSPs, for example) because of the risks posed by Monsoon fluctuations.

PMFBY offers comprehensive insurance protection against the cultivation loss, which helps to sustain farmers ' incomes and allows them to pursue creative practices. The Schema that covers all crops for which past yield data is provided and for which the required number of crop cutting experiments (CCEs) are carried out in the General Survey of Crop Estimation (GCES). For loan farmers who collect crop loans/KCC accounts for registered crops, the scheme is mandatory. For other farmers / non-loaners with insurable interests in the insured crop(s), however. For all the crops of Kharif Food \& Oilseeds, the average premium for farmers will be $2 \%$, for Rabi Food \& Oilseeds crops $1.5 \%$ and for Annual Commercial / Horticultural Crops 5\%. The Center and State shall share the difference between the premium and the insurance fee levied by farmers equally. The seasonal discipline of both loan and nonloan farmers shall be the same. AIC and other private general insurance companies will implement the scheme. The selection of the implementation agency (IA) will be conducted via bids by the coordinated State Government. 


\subsection{Pradhan Mantri Vaya Vandana Yojana(PMVVY)}

Based on the success and popularity of Varishtha Pension Bima Yojana 2003 (VPBY-2003) and Varishtha Pension Bima Yojana 2014 (VPBY-2014), as well as insurance against future interest income decreasing due to uncertainty on the market and to social security at an old age, the decision has been made to implement a simplified system of guaranteed pensions Towards' is introduced by India's Life Insurance Corporation (LIC). The scheme specifies that subscribers shall be given insure pension based on the fixed rate of return of $8 \%$ per month and payable annually at an initial lump sum, varying from a minimum purchase price of Rs. 1, 50,000/-for a minimum Rs. 1000/-per month to a maximum purchase price of Rs. 7, 50,000/for a maximum pension of rs. 5,000/-per month.

\section{DISCUSSION AND CONCLUSION}

A proactive approach is employed to generate leads for financial advisors, including by mailing and telesales, from the client base. Relations with a large number of customers who rarely or never visit a bank branch are increasing. Typically, financial planners are employed by the bank or construction company rather than the life company and usually receive a basic wage plus a bonus feature based on a combination of sales volumes, persistence and the product mix. Following the polarization reform, banks will be able to become multidistributors offering different suppliers with a variety of products. This can enhance the position of banking insurers by allowing them to meet the needs of their customers. The Indian government and regulatory authorities have recourse to each door in the country to ensure 100\% financial inclusion through various schemes, including PMJDY (Pradhan Mantri Jan Dhan Yojna), micro-insurance and microfinance. Bancassurance would be a great basis for building the foundations of $100 \%$ financial inclusion in such a setting. Bancassurance for all stakeholders will be a win-win scenario. Banking insurance is an important part of the upcoming financial marketplace in rapidly developing and developing countries with several benefits. For the sale of new insurance products, banks are using their current premises and employees (tellers and branch staff). This means that there are no additional operating costs for the sale of insurance. We also use the experience of the insurance company in the recruitment of bank staff and manufacturing insurance products. This rising distribution costs for insurers as well as banks and increases the competitiveness of the system. Banks also receive an increased return on their assets (ROA). Banks form banking partnerships because this is the only way they can sell insurance in most situations. This is attractive for the banks because there is a huge untapped chance for global insurance growth. Let us think about the other benefits they benefit from by entering into these relationships with insurance companies. The finding of the study concluded that the bancassurance schemes launched by the government of India and the schemes run by the private banks to increase the bancassurance percentage in the country are having significant positive results. There are still the number of issues needs to be addressed to achieve the $100 \%$ financial inclusion in the country.

\section{REFERENCES}

[1] M. Choudhury and R. Singh, "Customer's experience in Financial Inclusion through Bancassurance," J. Insur. Inst. India, vol. 2, no. 4, pp. 55-61, 2015.

[2] M. Kaur, "Bancassurance : A Base for Financial Inclusion," vol. 2, pp. 144-146, 2016.

[3] D. C. Washington, "Micro-Finance and Inclusive Financial Systems in Latin America Micro-Finance and Inclusive Financial Systems," 2010.

[4] M. J. McCord, C. Tatin-Jaleran, and M. Ingram, "The landscape of Microinsurance in Latin America and the Caribbean: a briefing note," p. 6, 2014. 
[5] "Measuring Financial Inclusion in Mexico CNBV's Approach to Obtaining better Data for Decision-Makers," Alliance Financ. Incl., p. 12, 2011.

[6] M. T. Manavi, "Defense Mechanisms against Distributed Denial of Service Attacks: A Survey," Comput. Electr. Eng., vol. 72, pp. 26-38, 2018.

[7] A. García-herrero and D. M. Turégano, "Financial Inclusion, Rather than size, is the Key to Tackling Income Inequality," BBVA Res., no. February, pp. 1-24, 2015.

[8] D. Tuesta, G. Sorensen, and A. Haring, "Financial Inclusion and its Determinants: the Case of Argentina," no. January, pp. 1-28, 2015.

[9] T. Wiechers, "Microinsurance and Social Protection," Discuss. Pap. \#003, pp. 1-27, 2013.

[10] N. RANGACHARY, "Insurance Regulatory and Development Authority Notification," DisClosure, vol. 2011, no. 2, pp. 1-216, 2002.

[11] J. P. Basu, "Microfinance and Women Empowerment An Empirical Study with special reference to West Bengal Microfinance and Women empowerment An Empirical Study with Special Reference to West Bengal, India," pp. 1-29.

[12] Merced Irrigation District, “Annual report,” p. 2, 1996.

[13] Micro-Credit Ratings International Limited, "Micro-Insurance Regulation in the Indian Financial Landscape," Development, p. 111, 2008.

[14] R. Lester, "Insurance and Inclusive Growth,” no. June, pp. 1-50, 2014.

[15] N. Dangi and P. Kumar, "Current Situation of Financial Inclusion in India and Its Future Visions," Int. J. Manag. Soc. Sci. Res. Int. Res. J. Consort., vol. 2, no. 8, pp. 2319-4421, 2013.

[16] W. Chopra, Puneet and Graham, "Financial Inclusion Through E / M-Banking," Microsave, 2011.

[17] M. Mehrpouya, A. Gisario, H. Huang, A. Rahimzadeh, and M. Elahinia, "Numerical Study for Prediction of Optimum Operational Parameters in Laser Welding of NiTi alloy," Opt. Laser Technol., vol. 118, no. February, pp. 159-169, 2019.

[18] C. Rangarajan, "Report of the Committee on Financial Inclusion," no. i, p. National Bank for Agriculture and Rural Developmen, 2008.

[19] Word Bank, "Financial Inclusion Strategies Reference Framework," no. June, p. 60, 2012.

[20] N. R. Kishor and B. Administration, "Micro Insurance in India-Protecting the Poor," vol. 2, no. 3, pp. 39-44, 2013.

[21] "IRDA - More on Micro Insurance."

[22] "Financial Inclusion in India: its Prospects, Scopes and Challenges Sujoy Kumar Dhar. Faculty Member IBS Business School, Kolkata.," pp. 1-41.

[23] Laxmi Mehar, "Financial Inclusion in India - An Assessment," Innov. J. Bus. Manag., no. July-August, pp. 42-46, 2014.

[24] M. K. Sharma and G. a N. Wright, "MicroSave India Focus Note 43," Time, no. April, pp. 2-3, 2010 .

[25] H. Kaur and S. Menani, "Bancassurance: A Step Towards Financial Inclusion," South Asian J. Mark. Manag. Res., vol. 7, no. 6, pp. 43-52, 2017.

[26] M. Kaur, "Impact of Bancassurance Product on Banking Business and Customer Satisfaction," vol. 5, no. 5, pp. 432-437, 2018.

[27] C. Churchill and M. Matul, Protecting the poor: A Microinsurance Compendium Volume II, vol. II. 2012. 
[28] I. Regulatory and D. Authority, “Annual report 2007 - 08," Gazette, 2007.

[29] I. Regulatory and D. Authority, "Development Authority," Gazette, 2008.

[30] R. Leith and R. Subramanian, Building supervisory Capacity to Create Inclusive Insurance Markets in the Pacific, no. November. 2013.

[31] P. J. Morgan and V. Pontines, "Financial Stability and Financial Inclusion," Asian Dev. Bank Inst., no. No.488, pp. 1-18, 2014.

[32] D. Acharya, S. Tapas, and K. Parida, "“Financial Inclusion in India: Why Not Happened," no. September, 2013.

[33] Premasis Mukherjee, A. Oza, L. Chassin, and R. Ruchismit, "The Landscape of Microinsurance in Asia and Oceania 2013," Munich Re Found. GIZ-RFPI Asia, p. 64, 2013.

[34] J. H. Gallaway, The Economics of Microfinance, vol. 41, no. 3. 2007.

[35] M. H. Elahinia, M. Hashemi, M. Tabesh, and S. B. Bhaduri, "Manufacturing and Processing of NiTi Implants: A Review," Prog. Mater. Sci., vol. 57, no. 5, pp. 911-946, 2012.

[36] F. Inclusion, W. Empowerment, S. O. F. M. Operations, and O. Issues, "The Micro FINANCE Review," vol. 1, no. 1, p. 194, 2009.

[37] M. N. Shah, S. Dixit, R. Kumar, R. Jain, and K. Anand, "Causes of Delays in Slum Reconstruction Projects in India," Int. J. Constr. Manag., pp. 1-16, Jan. 2019.

[38] S. Dixit, S. N. Mandal, J. V Thanikal, and K. Saurabh, "Evolution of Studies in Construction Productivity: A Systematic Literature Review (2006-2017)," Ain Shams Eng. J., 2019.

[39] S. Dixit, "ScienceDirect Analyzing the Impact of Construction Productivity Over Infra Projects : Indian Scenario," vol. 00, no. May, 2019.

[40] S. Dixit, "Analysing Enabling Factors Affecting the On-site Productivity in Indian Construction Industry," Period. Polytech. Archit., vol. 49, no. 2, pp. 185-193, Nov. 2018.

[41] S. Dixit, S. N. Mandal, J. V Thanikal, and K. Saurabh, "Study of Significant Factors Affecting Construction Productivity Using Relative Importance Index in Indian Construction Industry,” vol. 09010, 2019.

[42] F. Corman, A. D'Ariano, A. D. Marra, D. Pacciarelli, and M. Samà, "Integrating Train Scheduling and Delay Management in Real-Time Railway Traffic Control," Transp. Res. Part E Logist. Transp. Rev., vol. 105, pp. 213-239, 2017.

[43] I. Fisher and C. Bank, Irving Fisher Committee on Central Bank Statistics IFC Report Measures of Financial Inclusion - A Central Bank Perspective, no. June. 2016.

[44] J. Lowe and J. F. C. Tejada, "The Role of Livelihoods in Collective Engagement in Sustainable Integrated Coastal Management: Oslob Whale Sharks," Ocean Coast. Manag., no. May, pp. 1-13, 2018.

[45] R. Singh, B. B. Krishna, J. Kumar, and T. Bhaskar, "Opportunities for utilization of NonConventional Energy Sources for Biomass Pretreatment," Bioresour. Technol., vol. 199, pp. 398-407, 2016.

[46] P. Weekly, "Some Principles and a Case Design Study," vol. 42, no. 13, 2013.

[47] S. Taheri, "A Review on Five Key Sensors for Monitoring of Concrete Structures," Constr. Build. Mater., vol. 204, pp. 492-509, 2019.

[48] Bankable Frontier Associates, "Financial Inclusion Measurement for Regulators: Survey Design and Implementation," pp. 1-22, 2010. 
[49] J. Aduda and E. Kalunda, "Financial Inclusion and Financial Sector Stability with Reference to Kenya: A Review of Literature," J. Appl. Financ. Bank., vol. 2, no. 6, pp. 95-120, 2012.

[50] C. Sutton, "The Role of the Financial Services Sector in Expanding Economic Opportunity," Corp. Soc. Responsib., pp. 11-15, 2007.

[51] KPMG, "Insurance Industry - Road Ahead," pp. 1-40, 2013.

[52] A. Gardeva and E. Rhyne, "Opportunities and Obstacles to Financial Inclusion,” pp. 1-54, 2011.

[53] Bangko Sentral ng Pilipinas, "Report on the State of Financial Inclusion in the Philippines," Bsp, no. August, 2013.

[54] M. Chibba, "Financial Inclusion, Poverty Reduction and the Millennium Development Goals," Eur. J. Dev. Res., vol. 21, no. 2, pp. 213-230, 2009.

[55] A. Pouchous, "The Regulation and Supervision Main Issues and Progress," Int. Inst. Sustain. Dev., no. September, 2012.

[56] F. Atkiinson, A.; Messy, "Promoting Financial Inclusion Through Financial Education.pdf," OECD Publ., vol. 34, no. 34, pp. 1-53, 2013.

[57] R. Cull, A. Demirgüç-kunt, and T. Lyman, "Financial Inclusion and Stability:," CGAP $B r$., vol. May, no. 2008, pp. 1-4, 2012.

[58] L. Kumar and G. Balasubramanian, "NSE-IFMR" Financial Inclusion' Research Initiative," pp. 1-38, 2015.

[59] P. Weekly, "Financial Inclusion: and Issues Challenges," vol. 41, no. 41, pp. 4310-4313, 2016.

[60] P. Praba Devi, Bancassurance: A Marketing Perspective. International Journal of Civil Engineering and Technology, 10(3), 2019, pp. 2093-2102

[61] Ayushi Raichoudhury, Impact of Education on PMJDY Awareness and Financial Inclusion: A Study of Puri District, International Journal of Civil Engineering and Technology (IJCIET), 10 (1), 2019, pp. 220-226

[62] Ravikumar T, Measurement of Financial Inclusion Status of India, International Journal of Mechanical Engineering and Technology9(7), 2018, pp. 354-364

[63] Lakhwinder Kaur Dhillon and Dr. Upasana Srivastava, The Role of Various Financial Institutions and Regulatory Bodies in Financial Inclusion. Journal of Management, 5(3), 2018, pp. 69-79

[64] Lakhwinder Kaur Dhillon and Dr. Upasana Srivastava, To Examine the Policies and Initiatives Taken by the Regulatory Bodies for Financial Inclusion. Journal of Management, 5(3), 2018, pp. 103-116 